\title{
The influence of regional Italian images on consumer behaviour: a study of consumers in Germany
}

\author{
Simon Fauser ${ }^{1}$ (D) David Agola $^{1}$ (D)
}

Received: 30 January 2020 / Accepted: 5 January 2021 / Published online: 30 January 2021

(c) The Author(s) 2021

\begin{abstract}
The purpose of this paper is to investigate the influence of regional images of Italy on the purchase probability of wine. Instead of regarding country image as a homogeneous national construct, this article focuses on revealing regional differences in Italian country image and investigating whether they are related with purchase probability. Moreover, several scholars state, that the development of larger regional brands can improve consumer choice especially for the product wine. In the light of growing global competition from 'New World' wine countries and simultaneously decreasing competitivity of the main European wine-producing countries (including Italy), the possibility to actively shape the development of regional brands and thereby potentially strengthening the competitive advantage within the European Union and on a global level, seems to offer an adequate approach to maintain the leading role of Italian wine producers in European and international trade. Therefore, this study aims to test, whether using larger regions (and not specific wine regions) as origin information for wine is applicable and improving consumer choice. The empirical framework was tested on a random sample of consumers living in Germany and comprises (a) the description of image differences between Northern and Southern Italy, (b) measuring the influence of regional indication of origin on purchase probability, (c) determining the predictive value of image components for purchase probability, and (d) the investigation of moderation effects of country knowledge on the results. Data from 388 respondents were analysed using multiple linear regression and paired $t$ test. Results show significant image differences, which affects purchase probability. It is shown that the image of Southern Italy does not provide respondents with a suitable decision-making heuristic for buying wine. Furthermore, country knowledge negatively influences the predictive value of the measured regional image for purchase probability. As the predictive value of Southern Italian image does not contribute to the explanation of purchase probability, the present work corroborates the hypothesis of region-specific tendencies in the relationship between regional Italian image and consumer behaviour. Thus, this work provides a fundamental understanding of the regional composition
\end{abstract}

Extended author information available on the last page of the article 
of the Italian country image. It therefore serves practitioners as a decisional basis for the utilization of origin-related product information.

Keywords Country of origin · International marketing $\cdot$ Mezzogiorno $\cdot$ Consumer behaviour

\section{Introduction}

Research on the effect of origin information on product perception has been part of international marketing research for decades and there is a wide range of empirical evidence that supports the impact of country images on consumer perception. It is by now undisputed that it affects product perception and consumer buying behaviour (Mai 2011; De Nisco et al. 2016). The strength and valency of the influence varies between different product groups and is additionally dependent on antecedents and moderators of the country of origin construct (Ahmed and d'Astous 2008; Ahmed et al. 2004). These include the product and country knowledge of the consumer and personal involvement in the purchase decision (Celsi and Olson 1988). All these factors ultimately determine the level of positive attitude towards a country and thus the image of the product's country of origin (Bänsch 2002). Despite the theory's popularity in academia and the large research output it must be noted, that previous studies on the country of origin effect are mainly concerned with the investigation of a country image as a homogeneous national construct (Profeta 2006). More recent studies, however, indicate that regional differences and tendencies exist in the images of a country and that these have an influence on the perception of a product (Orth et al. 2005; Latusi et al. 2018). In this connection, the aim of this study is to contribute to an understanding of regional disparities in country image, by assessing how different image components of regions and their respective economy influence consumer behaviour. Within the framework of this study, the Italian North and South are taken as the object of investigation and tested on a sample of consumers in Germany. As it avoids a mismatch between consumers' perception of each Northern Italian or Southern Italian region and the product to be analysed (Roth and Romeo 1992), wine is chosen to be the subject of investigation. While there exists a plethora of different wine appellations and origin information gets increasingly fragmented (Chamorro et al. 2015), the question arises, whether using larger regional origin information improves customer evaluation (Atkin and Johnson 2010). In the light of an intensifying international competition, especially from the 'New world' countries, where (larger) regional brands are especially prevalent, this question is particularly pertinent. While Italy takes a leading role in international trade of wine, the country's regional disparities could counteract efforts to develop regional marketing strategies. 


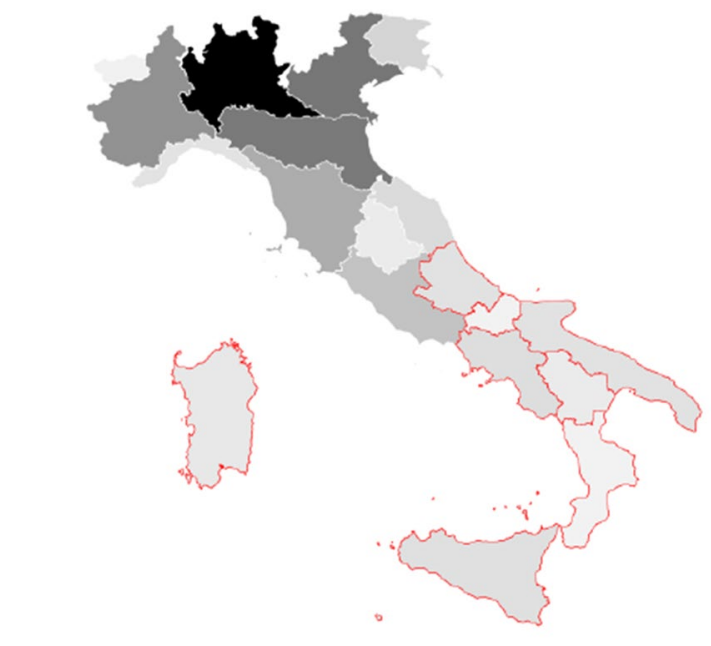

Export value 2017 (in million EUR)

401

120786

Fig. 1 Export values of the Italian regions in millions of Euros in 2017. Source: Own illustration based on ISTAT (2018)

\section{Evidence from Italy - the "Mezzogiorno"}

Besides regional disparities also in other European countries (i.e. for Germany see Fauser 2011), Italy can in this connection be regarded as an ideal example for existing regional disparities in country image, as economic and cultural disparities between Northern and Southern Italy and different self-images of the inhabitants of Italy indicate an unequal distribution of the positive image and thus, its effect on consumers (Kwon 2004).

While the general economic situation in Italy is deteriorating, as there are several problems like unimplemented reforms, high unemployment, rising economic crime and poverty among the population (Triulzi 2016), these problems are exacerbated by their unequal distribution. It can be observed that these developments are largely cushioned by the strong economic performance in Italy's North. On the other hand, the difficulties become particularly visible in Italy's South. An analysis of Northern and Southern Italy's share of international exports, for example, reveals the imbalance (see Fig. 1). In this context, the regions framed in red can be attributed to the Mezzogiorno (Southern Italy).

The economic disparities can be traced back to historical circumstances which promoted the economic development of Northern and Southern Italy to varying degrees. Since then, the North-South divide has shaped mutual cultural perceptions 
as well as the respective self-images (Jansen 2012). ${ }^{1}$ As a consequence, Southern Italy (commonly referred to as 'mezzogiorno') and its inhabitants are to this day regarded as 'backward', 'lazy', 'corrupt', 'uncivilized' and inclined to criminal and illegal behaviour. On the other hand, Northern Italy and Northern Italians tend to be associated with values such as honesty, diligence, education and economic performance (Kwon 2004; Messina 2018). While it is clear that these characteristics correspond to a stereotyped perception and are therefore not necessarily truthful, their existence and influence cannot be completely rejected. In the field of Consumer Behaviour, a study of Scarpa and Del Giudice (2004) has shown, that consumers in Milan (Northern Italy) tend to dislike Olive Oil from Southern Italy, and authors state 'that products from the South, that are elsewhere very welcome, may still encounter a veil of mistrust, possibly based on hard-to-die prejudice.'The authors additionally find this effect reversed for consumers in Naples (Southern Italy), concerning products from Northern/Central Italy.

Schooler (1965) states that regional jealousies, fears and animosities between inhabitants of a country can have an impact on the purchasers evaluation of consumer products. In times of weakening Italian domestic demand and increasing international competition, a positive country image is a fundamental competitive advantage that can support the increased export orientation of Italian companies. This enables Italian companies to differentiate effectively in consumer goods markets and increases purchase probability of Italian products (De Nisco and Mainolfi 2016).

In the following, the differences between Northern and Southern Italy, as explained above, are the basis of this work. Hence, the aim is not to analyse single Italian regions with regard to their image, but to consider Northern and Southern Italy as mutually different and internally quite homogenous regions. Even though of course there also may exist differences amongst regions in the South or in the North of Italy and this concept may often be driven by stereotypes, the concept of the North-South divide is overarching those regions. The object of the analysis is thus the question whether the aforementioned discrepancies consist in the perception of consumers outside Italy as well and influence consumer choice. As it is assumed, that consumers in Germany, especially those with a low knowledge of Italy and its regional structures, are not as aware of the exact partition of Italian regions and their belonging to the 'Mezzogiorno', as Italian consumers, the usage of a North-South divide in this study is chosen and may be preferred over an exact North-CentreSouth subdivision. Same applies to the usage of a broad North-South denomination, instead of selecting representative Italian regions from the North and from the South for the purpose of this analysis, as consumers in Germany could confuse whether the selected representative region should be attributed to the North or the South of Italy, especially those with a low country knowledge. Scarpa and Del Giudice (2004) used a similar approach, conceptualizing origin also as a North-South dichotomy and found the effects of origin information amongst consumers in Italy as complex. Although they assign the central region to the north of Italy, they also

\footnotetext{
${ }^{1}$ For a detailed discussion of this topic, see Amyot (2004); Jansen (2012).
} 


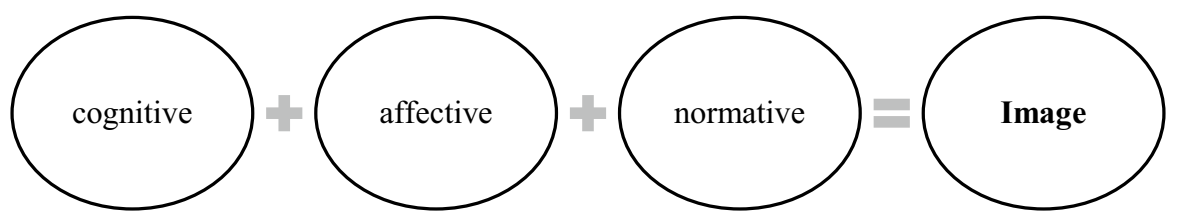

Fig. 2 Components of an image. Source: Own representation

speak of a dichotomy. Based on the economic characteristics (in this work based on export, see Fig. 1), an allocation of the centre to the south is chosen.

\section{Theoretical framework}

\subsection{Characteristics of a country image}

In addition to the multitude of research work that conceptualizes country images and the country of origin effect from different viewpoints (e.g. Ahmed and d'Astous 2008; Roth and Diamantopoulos 2009; Bergler 2013; Buhmann 2016), the term 'image' can be fundamentally described as the character of an object (e.g. a country or region) perceived by an individual, which is based on an accumulation of organized associations in the cognitive system of the individual. It thus, consists of a construct of past and future assumptions about the characteristics and attributes of an object, rather than a mere objective description of it. This construct does not necessarily have to be clearly defined and differentiated, but can consist of specific memories and opinions about the object, which are more or less strongly connected with each other. The image can therefore be coherent, although it contains contrasts and ambiguities (Kelman 1965). In this context, the cognitive component of an image is spoken of (Verlegh and Steenkamp 1999).

On the other hand, there is the affective component of an image, which does not consist of an evaluation of assumed characteristics of an object composed by several interrelated assumptions, but inevitably makes a general judgement about the emotional appeal of an object (Bergler 2013). In other words: Individuals associate positive or negative emotions with a country or region, which shape individual judgement formation. These often arise from social or political dimensions of a country's image (Maheswaran and Chen 2006).

Furthermore, each individual is integrated into a social structure whose members are in permanent and mutual contact (Zajonc and Markus 1982). This network of relationships creates a sense of community between individuals that manifests itself in common goals, values and norms (Wallendorf and Reilly 1983). Since individuals are constantly striving to meet the expectations and behavioural norms of their social environment, the image of a country can be negatively influenced if it conflicts with the norms and values underlying an individual and thus forms the normative component of a country image (Klein et al. 2004). 
While this is the general definition of an image (see Fig. 2), according to Kühn (1993), the term country image is to be further differentiated between the live-in image and the made-in image. The live-in image describes the country's image as a socio-cultural area and contains judgments about the history and traditions of a country, economic status, social culture, norms and values, as well as its political organization (Buhmann 2016). It thus, mainly comprises affective and normative and cognitive aspects of the country's image, that are not related to a specific product.

The made-in image, on the other hand, does not describe the concept of a country as a socio-cultural area, but as a place of origin of economic goods services and is therefore the sum of product-related beliefs about the country of origin. According to Kühn (1993), the made-in image comprises the following characteristics:

- Characteristics of the country's products

- Characteristics of the country's enterprises

- image-shaping industries

- image-shaping companies

It should be remarked in this context, that this perception is largely influenced by those companies and sectors which are particularly active on an international level (Kühn 1993). In the case of Italy, these are likely to be products from the consumer goods sector such as food and beverages, textiles, clothing and leather goods, as well as accessories, which, due to their high international visibility, are particularly attributable to the export-driven North of Italy (ISTAT 2018).

While positive experiences with a country's cultural dimensions can be positively linked with a country's image (which takes into account the dimension of the abovementioned live-in image), also positive experiences with products from a certain country can influence country image positively (Martin and Eroglu 1993; Ryu et al. 2016).

\subsection{Extrinsic cues in consumers' product evaluation}

Uncertainty about the true characteristics of a product is a widespread problem for consumers in goods and services markets. It is almost impossible for consumers to value goods reliably before they are used. The increasing product complexity and wealth of information intensifies the problem that consumers face when making purchasing decisions (Shapiro 1982).

Due to this complexity and wealth of information, activating processes exist based on a learning-theoretical approach, which initialize an individual's reaction to stimuli. These manifest themselves as constructs called "emotion", "motivation" and "attitude". As these constructs differ only slightly from each other, a clear demarcation therefore does not seem to make sense (Bänsch 2002). Figure 3 serves as an example of how an image works as an extrinsic cue. In a theoretical learning approach, signals and information from the environment are abstracted and generalized. Together both processes are referred to as categorization and are derived from 


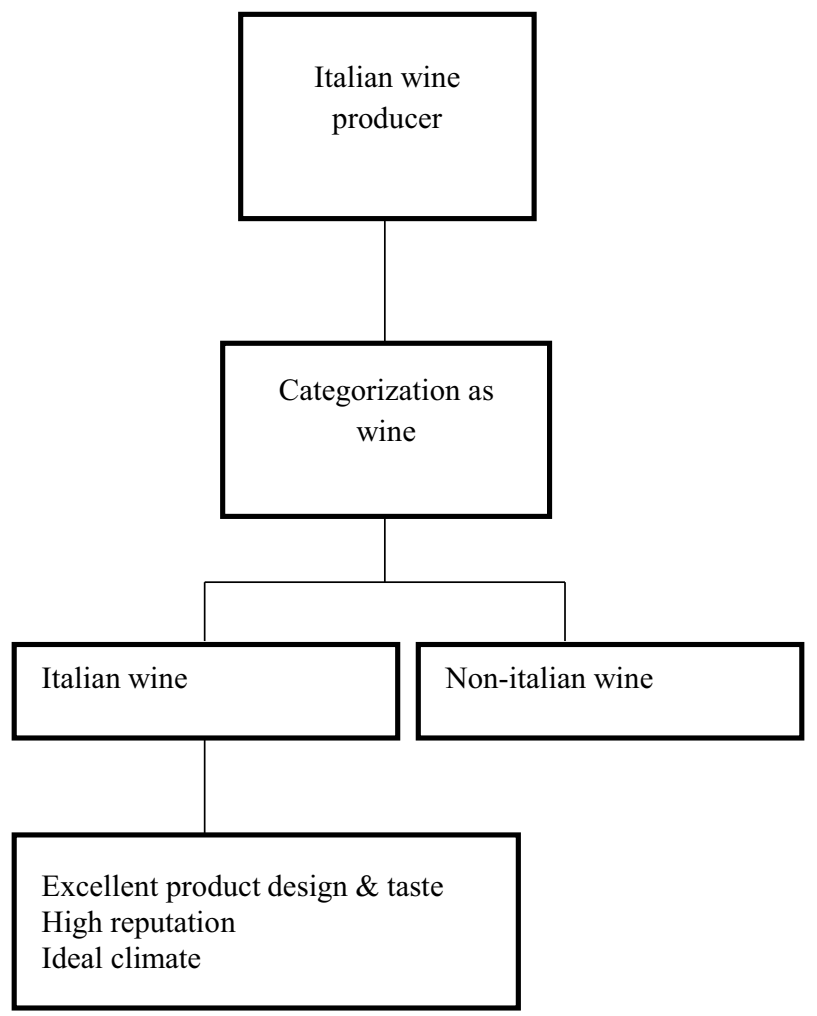

Fig. 3 Effect of an image from a learning-theoretical point of view. Source: Own representation based on Profeta (2006)

learning theory (Bruner et al. 1956). It is therefore sufficient for consumers to perceive and assign a reference stimulus to an existing category in order to activate the individual's perception of the country or region and the associated attitudes towards it. By using symbols such as country names on products, categories and their attributes are quickly remembered, which has a lasting influence on the perception and evaluation of products (Profeta 2006).

Hence, according to Okechuku (1994), an indication of origin on a product or its country-typical appearance can be seen as an important extrinsic cue influencing product perception. In this way, consumers use extrinsic product characteristics as a basis for purchasing decisions and derive the intrinsic (difficult to evaluate) product characteristics.

\subsection{Factors determining and moderating the influence of country image on consumer behaviour}

According to Mai (2011), it is almost impossible to make general statements about the influence of country image, as it depends on an abundance of influencing 
factors. ${ }^{2}$ As a result, a distinction is made between moderators and antecedents of the country of origin effect (Ahmed and d'Astous 2008).

\subsubsection{Moderating factors of the country of origin effect}

Moderator variables are defined as those variables which intensify or weaken the country of origin effect. In addition, these variables moderate the extent to which the attitude towards the country of origin influences the concrete behavioural intention, as consumers use product-related characteristics in their decision-making process for product evaluation. Regarding the moderator country knowledge, this means that consumers having little familiarity with products from a country (or region), with the help of extrinsic cues such as indication of origin, refer to the live-in image as a proxy for the true product performance during purchase decision (Foscht et al. 2017). In other words: A positive country image influences purchase probability positively, when product-specific knowledge is low. Consequently, low familiarity with a certain product increases the probability of the existence of halo effects (Park et al. 2011).

On the other hand, if the consumer already has a high level of product specific knowledge during the purchasing process and origin information is available, the sum of experience with different products from the same country of origin is used as a proxy (Bloemer et al. 2009). The familiarity with products from a certain country or region and thus a high level of country knowledge forms a direct influence on product evaluation, which is theorized as a summary-construct (Han 1989). In conclusion, this means, that the less consumers know about the product to be evaluated during purchasing process, the more the general country image and stereotypical beliefs about a country will be used for evaluation, given that origin information is available (Laroche et al. 2005).

\subsubsection{Antecedents of the country of origin effect}

For an integrative conceptualisation of the country of origin effect, sociodemographic and psychographic antecedents of the country of origin effect also have to be taken into account. Previous research has shown that sociodemographic antecedents such as age, gender and educational level influence the impact of the country of origin effect on consumer behaviour (Wall and Heslop 1986), as well as socioeconomic status (Samiee et al. 2005).

In addition to sociodemographic aspects, affinity or animosity towards the country of origin are seen as influencing parameters (Hoffmann et al. 2014). These are regarded as psychographic factors and are understood as a positive or negative attitude towards the country of origin of a product. Although several studies support the influence of affective processes on consumer choice and suggest an influence on purchasing behaviour (Oberecker et al. 2008), the focus has been on other

\footnotetext{
2 Since the theoretical basis for country of origin effects is identical to that of the region of origin effect, both terms are used synonymously in this article (Profeta 2006).
} 
psychographic factors such as the constructs of national identity, nationalism, cosmopolitanism and internationalism of country assessment (Mai 2011). Studies however show, that the influence of affective processes can be more influential than that of the cognitive component and that the effect has been demonstrated for products in general and for specific product groups (De Nisco et al. 2016).

As a consequence, if the origin of a product is perceived by the consumer through its country- or region-specific labelling or appearance, the attitude towards and perception of the product is influenced. This effect is not exclusively utilitarian in nature (i.e. an indication of high product quality). Rather, consumers associate positive or negative emotions with certain countries or regions, which shape their individual judgement of the product. Some consumers associate the purchase of products with prestige, pride or sympathy. Others, may feel a sense of antipathy. The resulting rejection of products manufactured in the region of origin has a negative impact on the purchase decision and can even lead to a refusal to buy (Mai 2011). Affective processes thus represent the emotional evaluation of the country image and influences consumer behaviour (Lebrenz 1996).

Where the knowledge about values and norms related to the region of origin of the product touches those represented by the consumer, this is reflected in consumer judgement (Mai 2011). The influence of the social group and hence normative processes on consumer behaviour is particularly prevalent for socially visible products. The prerequisite in this regard is that these products receive attention from the social environment and have a high social symbolic value for the consumer. Accordingly, products with such characteristics trigger pressure for conformity, as they can be perceived and evaluated by the social peer-group (Kroeber-Riel and Gröppel-Klein 2013). While measuring the impact of normative perceptions and their effect on consumer choice has been demonstrated for specific antecedents such as cosmopolitanism, ethnocentrism, national identity, nationalism, or internationalism (Roth and Diamantopoulos 2009; Mai 2011), this work conceptualizes normative aspects as part of country image.

Summarized, the effect, that the place of origin has on the consumer can be seen as a 'set of strengths and weaknesses linked to the place-of-origin that add or detract value from the product for consumers' (Papadopoulos and Heslop 2003). Thus, for information-economic motives the region of origin can serve as a surrogate for the nature of a product in order to simplify the necessary cognitive information processing (Pharr 2015).

\subsection{Region of origin and wine}

In addition to the general characteristics of intrinsic or extrinsic cues that activate different (cognitive, affective and normative) processes, some products and their respective extrinsic cues seem to trigger those processes more intensively. Specifically for wine, this seems to be true. Johnson and Bruwer (2007), who studied the regional brand images of wine cultivation areas within California and their influence on perceived wine quality, found, that providing regional information on a wine label, increased consumers confidence in the quality of the product. While the 
importance of indications of origin varies in different countries, a general effect is found in a plethora of studies analysing the importance of wines' place of origin. So, while there is a broad consensus that indication of origin adds value to wine, some studies' inconsistent results reveal the need of a further analysis on how these inconsistencies can be understood. One question is about the geographic detail that consumers prefer in their decision-making process. As indications of origin tendentially appear to get increasingly more fragmented (Chamorro et al. 2015), Atkin and Johnson (2010) propose using larger regions when developing marketing strategies. Moreover, the positive value adding effect of a regional brand depends on its relative strength (Lockshin et al. 2006) and its collective reputation (Winfree and McCluskey 2005). These remarks illustrate the challenge for some regions, which is 'that their image is not one that their member wineries would wish to emphasize or attach themselves strongly to.' (Johnson and Bruwer 2007).

On the basis of the considerations in Sect. 1, the question arises whether this is the case for Italy. Building on the general discussion on the degree of fragmentation regarding wine indications of origin and the statements of Atkin and Johnson (2010), which recommend larger regions in marketing practice, this study addresses this very issue.

According to the Italian Ministry of Agricultural, Food and Forestry Policies (MiPAAF), Italy is the European country with the highest number of agricultural and food products with designation of origin and geographical indication recognized by the European Union. Additionally, there exists an appellations system for wines in Italy, with currently 524 certified wines (MiPAAF 2020). The appellations represent an approach to ensure highest quality standards and only a small number of wines are authorized to carry the highest quality seal.

From an involvement point of view, consumers who are certain that specific products are strongly linked to personal values and goals (see Sect. 2.3.2), tend to exhibit a higher degree of involvement (Kraigher-Krainer 2007). On the other hand, if the product attributes are only weakly linked to personal values and goals, low involvement is expected and specific product information (such as appellations) is not being processed (Peter and Olson 2010). While the above-mentioned classifications and fragmented geographical information may give wine connoisseurs with personal interest in wine and therefore high involvement an indication of high product quality and low risk, it remains questionable whether this is also the case for consumers with low involvement, who are not familiar with grape varieties and cultivation areas. Especially for this group of consumers it seems plausible to use (larger) regional indications for the purpose of risk reduction and decision making. Still, also in a high-involvement setting, consumers with low brand familiarity use regional indications of origin as a proxy (Koschate-Fischer et al. 2012). So for both involvement levels, larger regional indication of origin could be a suitable approach.

While especially the New World wine countries, such as Australia and the United States of America, have put a focus on building larger regional brands, the European wine market despite of its intensive growth and significance as the world's largest wine-producing and wine-exporting region (Correia et al. 2019), has remained fragmented and attached to the concept of terroir (Tustin and Lockshin 2001; Pucci et al. 2014). In fact, as Conca Messina et al. (2019) note, 'only for the mass media 
and the statistics, it exists a French (or an Italian or a Spanish, etc.) wine: in the real oenologic world there only exist the wine regions of Barolo, Bordeaux, Champagne, Chianti, La Rioja, Tokaj etc. 'Consequently, existing findings are mainly grounded on these specific indications of origin, which are linked to specific and generally well-known wine-growing regions.

In the light of growing global competition from New World wine countries and simultaneously decreasing competitivity of the main European wine-producing countries (including Italy) (Balogh and Jámbor 2017), the possibility to actively shape the development of regional brands and thereby potentially strengthening the competitive advantage within the European Union and on a global level, seems to offer an adequate approach to maintain the leading role of Italian wine producers in European and international trade.

Therefore, this study aims to test, whether using larger regions (and not specific wine regions) as origin information for wine is applicable and improving consumers willingness to buy. In detail, the central question is, if giving information on the (northern or southern Italian) regional descent of the product positively influences consumers' willingness to buy. Hence, the basis of this study is not the analysis of the image of Italian wine on consumers, but the analysis of the image of North and South Italy and its influence on consumers evaluation, taking into account the considerations in Sect. 1.

\section{The role of attitude in purchasing behaviour theory}

Many scholars emphasize the interrelation between cognitive and affective components of country image (Lebrenz 1996; Roth and Diamantopoulos 2009). Additionally, normative dimensions are substantial for the understanding of country images. Therefore, in this paper the positive attitude is seen as the interplay between the cognitive, affective and normative components, as the influence of the country or region of origin cannot be regarded exclusively as an indication for product quality. It also conveys a symbolic and emotional meaning for the consumer (Verlegh and Steenkamp 1999), since the consumer associates a specific product with a national (regional) identity, which results in a more or less strong affective and normative influence on certain products. For instance, the positive influence of an Italian indication of origin is higher, the more extensive and intense the emotional bond and sympathy (affect) to Italy is and the more likely the consumer identifies himself with the norms associated with Italy (Fournier 1998). If there is a negative attitude towards a country, the consumer does not only process information intensively (cognitive component). Emotions such as anger or frustration are also activated (affective component), which may result from a norm violation (normative component). Accordingly, the country of origin is not only a cognitive key indicator for perceived product quality, but also an influential determinant for general product perception and consumer preferences in relation to different products from a country (Verlegh and Steenkamp 1999). While there exists a multitude of different conceptualizations of the effect that country image has on consumers from considering cultural and social dimensions 
of a country to product-related features (Roth and Diamantopoulos 2009; Andéhn et al. 2016), the object of investigation in this work is country image, which is expressed by attitude.

Previous study findings showed positive associations between country image and product evaluation within different product categories and countries. Meaning, that consumers that evaluated products positively, had a favourable attitude towards the respective country (White 2012; Ryu et al. 2016). Therefore, within the scope of this work, a positive relationship between attitude (represented by image) and purchase probability is assumed. Looking at the German market, Koschate-Fischer et al. (2012) found that consumers from Germany were more willing to pay price premiums for branded products from countries with a favourable country image. Focusing on Italian products, Pucci et al. (2017) provided insight into the influence of Italian country image on consumer behaviour in emerging countries. They found, that a favourable Italian country image in some cases increases willingness to pay a price premium for fashion products, but that the influence is varying among the analysed countries. While these findings focus on emerging countries, this paper addresses a developed country. In 2018, Germany represented the most important target market for Italian products worldwide (ISTAT 2019). Simultaneously, Italy is one of the most important countries of origin for German imports (BMWi 2019). In view of these particularly close Italo-German commercial relations, the consumer from Germany represents a relevant object of investigation.

According to Profeta (2006), the derivation of regional images instead of general national images can provide an explanation for country of origin effects that have been only imperfectly understood so far. Beyond that, van Ittersum (2002) points out that, 'since a region within a country is more homogeneous than a country, a regional indication may provide a more consistent image. Consequently, a regional indication is expected to offer better opportunities for differentiating products than a country-of-origin label.' Hence, recent studies point to a region-specific country of origin effect (Orth et al. 2005). Their findings show that effects of origin tend to be region-specific and certain products are subject to a stronger regional effect than others. Thus Latusi et al. (2018) argue analogously, that the link between a geographical (regional) indication and the product wine helps to reduce consumer's risk perception by also reducing concern about the origin and production method of the product. Regional indications of origin can thus serve as an extrinsic cue for perception differentiation and risk reduction on a regional basis, which ultimately leads to an increase in purchase probability (Latusi et al. 2018). As a limiting factor, Waiguny et al. (2017) state that regional indications only constitute an advantage on condition that customers have a connection to the country or region and associate the corresponding wine with the region. Moreover, it adds that only a positive image of the region has an influence on the image of specific products from that region. Thus, the purchase probability for these products is only increased if the image corresponding to the region is positive in the consumer's perception (von Alvensleben 2001).

As Roth and Romeo (1992) additionally point out, the likelihood of buying a product will decrease if a mismatch between a specific product and the origin of it is evident. Vice versa, 'a product country match should occur when important 
dimensions for a product category are also associated with a country's image.' (Roth and Romeo 1992).

A recent study by Future Brand (2015), states that in this context the positive perception of Italian products is ranked fifth in the corresponding ranking, while food and beverages are ranked second in the ranking. On this basis the product wine is used for the analysis, since it is assumed that this avoids a mismatch for Northern Italy, as well as Southern Italy.

Lastly, as a meta-analysis by Peterson and Jolibert (1995) shows, the country of manufacture explains on average 30 percent of the perceived quality of a product, but only 19 percent of the purchase intention, this article has the aim to capture the interrelation between image and purchase probability for wine from Italy. It follows that, within the framework of this article, it is required to measure not only the cognitive component of attitudes towards the region, but also the affective and normative components derived theoretically in the preceding sections.

The image construct is increasingly seen as functionally identical with the attitude construct, which makes separate treatment obsolete (Bänsch 2002). For this reason, the positive attitude is measured using the image dimensions, which are discussed in the previous paragraphs.

Based on the preceding sections, the aim of this article is on the following research questions:

1. Do there exist image differences between Northern Italy and Southern Italy?

2. Which of the image components do differ significantly between Northern Italy and Southern Italy?

3. Does purchase probability increase with the strength of positive attitude/image?

4. Does country knowledge moderate the influence of region image on purchase probability?

\section{Methodology}

In order to achieve a sufficiently large sample, an online survey was chosen for data collection. This type of survey ensures a wide coverage, as in 2018, 81 percent of the population in Germany was using the Internet. In that connection, the number of online surveys has evolved to become the central method of survey in market research since first being used in 1998. In 2017, 38 percent of surveys were carried out as online surveys. This makes this survey type the most frequent use in market research practice (ADM 2018). Various channels (e.g. social media, newsletter, QR codes) were used to achieve a wide distribution of the online questionnaire. These consist of distributing the online link to the questionnaire via the faculty-wide mail distribution list of the Faculty of International Business at Heilbronn University, the usage of an online platform for survey projects ("Surveycircle") and distributing the survey via social media (privately and via the distribution in groups with a connection to Italy-related issues on various social networks). Lastly, printed QR codes containing a link to the survey were distributed amongst the population in various areas such as shopping streets and parks. The survey period was three weeks, which 
resulted in a total of 796 participants. Among the submitted online questionnaires, those that had an unrealistically short completion time were sorted out. In addition, for each variable it was ensured that the variables had a sufficient sample size. As a result, the final sample size is 388 persons. Similar studies on the country of origin effect showed a similar sample size (Allred et al. 2000 ; Lee and Ganesh 1999; d'Astous and Boujbel 2007; Ryu et al. 2016).

In order to measure the image respectively the strength of the positive attitude towards a region, 27 items were included in the questionnaire. These are based on the work of Ghvanidze (2012) and Buhmann (2016). In this way, the three components (normative, cognitive, affective) of the attitude construct are adequately captured and comprise statements related to the image components (see Appendix in Table 5). The evaluation of general attitudes towards products instead of specific products when measuring country image is chosen and justified by other scholars (Laroche et al. 2005, Ryu et al. 2016).

In order to connect the attitude construct with the purchase probability, the respondents indicate the probability of buying the product wine on a single item 5-point-scale ("The probability, that I buy this wine is..."; from "very high" to "very low"). These purchase probabilities were given for three product alternatives. Firstly, for (1) wine without origin information, (2) wine with North Italian origin information and (3) wine with South Italian origin information. In order to keep the effect of regional indications of origin uninfluenced by brand familiarity and product knowledge, specific brand references, grape varieties and wine cultivation areas were omitted. This ensures that the same basis of information and evaluation is provided for both potentially occurring degrees of involvement in the product wine. Additionally, the intent of this study is to test theoretical considerations and not actual branded products or specific wine cultivation areas.

All statistical analyses were performed using IBM SPSS Statistics. A reliability analysis is carried out, before performing value comparisons of the mean to identify image differences between Northern and Southern Italy. Same applies to the multiple linear regression, which is performed in order to determine the explanatory value of the image for purchase probability. This is necessary in order to summarise the various items formulated in the questionnaire to the image constructs comprising the three components of an image described earlier. The internal consistency, described by Cronbach's alpha, of the items for measuring the cognitive components of Northern Italy $(\alpha=0.918)$ and Southern Italy $(\alpha=0.914)$ is very high, which makes it possible to aggregate them into one value. The same applies to the affective components of Northern Italy $(\alpha=0.877)$ and Southern Italy $(\alpha=0.917)$ (Blanz 2015). The Spearman-Brown coefficient is used to measure the normative component with two items (Eisinga et al. 2013), which shows good values for the normative component of Northern Italy $(\rho=0.731)$ and Southern Italy $(\rho=0.773)$ and thus all items can be aggregated into three components (see Appendix in Table 6).

To analyse the effect of country knowledge on the level of positive attitude, the sample was subdivided into two subgroups. The group subdivision is based on the aided awareness of Italian regions. On average, 8.08 Italian regions are known to the respondents. Thus, the limit for the sample subdivision is 8 known regions. Respondents who know 8 or less than 8 Italian regions belong to the subgroup of 
Table 1 Mean value differences of the image dimensions of Northern and Southern Italy. Source: Own evaluation

\begin{tabular}{llllll}
\hline Image component & Mean & SD & T & Significance & $\begin{array}{l}\text { Effect size } \\
\text { (Cohen`s } \\
\text { d) }\end{array}$ \\
\hline Affective & $4.132(3.982)$ & $0.660(.804)$ & 3.292 & 0.01 & 0.168 \\
Normative & $3.317(2.947)$ & $0.699(.813)$ & 7.959 & 0.00 & 0.408 \\
Cognitive & $3.260(2.696)$ & $0.637(.648)$ & 12.729 & 0.00 & 0.592 \\
\hline
\end{tabular}

Values in brackets $=$ Southern Italy, $\mathrm{n}=388$; significance level $p<0.05$

respondents with low country knowledge. Respondents who know more than 8 Italian regions belong to the subgroup of respondents with high country knowledge. This corresponds to 238 respondents with low country knowledge and 150 respondents with high country knowledge.

\section{Results}

\subsection{Differences of regional image}

In order to take research question 1 and 2 into account and to reveal possible imagerelated regional disparities between Northern and Southern Italy, a paired t-test was carried out, comparing the mean values of the image constructs measured. The mean values in Table 1 are derived from the aggregation of the different measured items into the respective image components. All items are inverted, so higher values indicate increasing positive attitudes towards the region. A value of 1 therefore indicates a low image value ("do not agree at all"), a high value of 5 indicates a very positive image ("fully agree"). The values in brackets show the results of the analysis for Southern Italy, the values not bracketed show the mean values for Northern Italy.

The analysis of mean differences is preceded by a test for normal distribution, which was performed using the Kolmogorov-Smirnov test. Analysis shows, that the variables are not normally distributed (see Appendix in Table 7). Despite this, a t-test can be performed, since for large sample sizes $(n>30)$ the t-test reacts robustly to these assumptions (Bortz and Schuster 2010). This requirement is met since the sample size in all cases significantly exceeds this limit. Finally, the effect strength of the significant mean differences was determined using Cohens $\mathrm{d}$.

There are highly significant differences between Northern and Southern Italy in all components. While the sympathy to Northern and Southern Italy is strong in both cases, Northern Italy benefits from a significantly better sympathy value $(\mathrm{M}=4.132, \mathrm{SD}=0.660, \mathrm{~d}=0.168)$ than Southern Italy $(\mathrm{M}=3.982, \mathrm{SD}=0.804$, $\mathrm{d}=0.168$ ). Italy in general, and Northern Italy in particular, enjoys a high degree of sympathy among consumers in Germany, which is represented in the low effect size of Cohen's d. At the same time, it can be observed that the norms and values represented by the Northern and Southern Italian population are less compatible 
Table 2 Mean value differences between the purchase probabilities of Northern and Southern Italian wine and wine without origin information. Source: Own evaluation

\begin{tabular}{llllll}
\hline Product & $\begin{array}{l}\text { Country } \\
\text { knowledge }\end{array}$ & Mean value & SD & Significance & $\begin{array}{l}\text { Effect size } \\
\text { (Cohen's d) }\end{array}$ \\
\hline Wine (North) & low & $2.947(1.967)$ & $1.131(1.104)$ & 0.000 & 0.877 \\
& high & $2.753(1.673)$ & $0.995(0.884)$ & 0.000 & 1.148 \\
Wine (South) & low & $2.489(1.967)$ & $0.831(1.104)$ & 0.000 & 0.534 \\
& high & $2.460(1.673)$ & $0.864(0.884)$ & 0.000 & 0.900 \\
\hline
\end{tabular}

Values in brackets $=$ Results for products without indication of origin, $n=388$

with the values and norms of the respondents. In this case the respondents see the Northern Italian population as normatively closer to their own values than is the case for Southern Italy (being $\mathrm{M}=3.317, \mathrm{SD}=0.699, \mathrm{~d}=0.408$ for North, compared to $\mathrm{M}=2.947, \mathrm{SD}=0.813, \mathrm{~d}=0.408$ for South), with Cohen's $\mathrm{d}$ showing a medium effect size, which may be explained by a higher cultural proximity of Northern Italy to Germany.

The greatest difference in mean values is ultimately revealed in the image of the regions as places of origin of economic goods and services. The respondents see Northern Italy by far as economically more developed and as a producer of higher quality goods $(\mathrm{M}=3.260, \mathrm{SD}=0.637, \mathrm{~d}=0.592)$. The image of Southern Italy, on the other hand, differs significantly from that of Northern Italy and shows a significantly lower value $(\mathrm{M}=2.696, \mathrm{SD}=0.637, \mathrm{~d}=0.592)$, with Cohen's $\mathrm{d}$ of 0.592 it can be observed that the economic image differs strongly between the regions and indicates a strong effect (Cohen 1988). Thus, the evaluation of the economic performance of the respective region is seen as diverging within Italy.

Consequently, it is concluded that based on research question 1 and 2, image components in all cases differ significantly from each other. Therefore, another North-South divide can be identified, which is present in the perception of consumers in Germany and is specifically strong in the cognitive dimension of the respective images. The results show that the respondents mainly associate Northern Italy with the economic dimension of an image and see the Northern Italian cultural norms and values as more compatible with the own norms and values represented. While both regions benefit from high sympathy values, Northern Italy is still characterized by a significantly better image value in the affective component. It is thus evident that the statement made in the introduction, which identifies Southern Italy from an internal Italian point of view as a focal point for economic and social differences, is also valid for the present sample of consumers in Germany.

\subsection{Effect of indication of regional origin on purchase probability}

With reference to research questions 3 and 4, the following paired t-test serves the purpose of investigating whether a North or South Italian indication of origin per se influences purchase probability measured on a single-item 5-point-scale in this work. A value of 1 therefore indicates a low purchase probability, a high value 
of 5 indicates a high purchase probability. The following analysis thus describes the strength of the effect of Northern and Southern Italian origin information on the purchase probability compared to products without origin information. The Kolmogorov-Smirnov test for normal distribution shows a violation of this precondition (see Appendix in Table 8). In this case, analogous to Sect. 5.1, a paired t-test can still be performed, since the sample size clearly exceeds the value of 30 (Table 2).

The strongest effect of an indication of origin on the purchase probability is given with wine of Northern Italian origin. The mean value of $2.947(p=0.000$; $\mathrm{SD}=1.131 ; \mathrm{d}=0.877$ ), which represents the purchase probability, differs at a significance level of $\mathrm{p}<0.001$ highly significant from the purchase probability of a product without indication of origin among respondents with low country knowledge. There is a high effect size, since Cohen's d clearly exceeds the value of 0.5 (Cohen 1988). An increase in the respondents' country knowledge further strengthens the influence of Northern Italian indication of origin. With a mean value of 2.753 $(p=0.000 ; S D=0.995 ; d=1.148)$, we can state a strong effect of a Northern Italian origin information, since the mean value differences between wine without origin information and wine with Northern Italian origin information are highly significant with $\mathrm{p}<0.001$ and Cohens $\mathrm{d}=1.148$ indicates a very strong effect. Highly significant mean value differences were also found for wine with Southern Italian origin information. The purchase probability of respondents with low country knowledge at a significance level of $\mathrm{p}<0.001$ is significantly influenced by Southern Italian indication of origin. The mean value for the purchase probability of Southern Italian wine is $2.489(\mathrm{p}=0.000 ; \mathrm{SD}=0.831 ; \mathrm{d}=0.534)$ and thus differs widely from the purchase probability for a wine without indication of origin. With $d=0.534 \mathrm{a}$ strong effect is evident. The influence of an indication of origin increases further with an increasing country knowledge. Thus, the influence of Southern Italian origin information on the purchase probability of the subgroup of respondents with a high level of country knowledge increases. The mean value amounts to 2.460 ( $p=0.000$; $\mathrm{SD}=0.864 ; \mathrm{d}=0.900)$ and thus differs significantly from the purchase probability of a wine without indication of origin. The effect strength totals $d=0.900$ and can therefore be regarded as very strong. It is noted that it is not the purchase probability of a wine from Southern Italy that increases, but the purchase probability of a wine without origin information decreases. This indicates a greater importance of indication of origin for respondents with a high level of country knowledge, for both Northern Italian and Southern Italian wine.

It is therefore to be noted that Italian origin information for wine has a very strong influence on purchase probability. This can be observed particularly with Northern Italian wine. But also Southern Italian wine benefits in a positive sense from a Southern Italian indication of origin. With increasing country knowledge, the purchase probability of wines with Italian indication of origin also increases, which is especially true for Northern Italian wines. In general, the effect sizes of wines with a North Italian indication of origin are higher than those of wines with a South Italian indication. With reference to Sect. 2.4, it shows that the use of larger regions leads to an increase in the probability of purchase. Northern Italian wine in particular benefits thereby from regional indications of origin. 


\subsection{Region image as explanatory variables of purchase probability}

After the general influence of Italian indications of origin on the purchase probability having empirically been demonstrated, it will be discussed whether regional image components that have been described previously are of explanatory power and influence the purchase probability. The results of a multiple linear regression analysis for the product wine from Northern Italy show the following results. With an $F$ value of $F(d f=3,225)=25.300$ for the subgroup of respondents with low country knowledge and $\mathrm{F}(\mathrm{df}=3,142)=9.603$ for respondents with high country knowledge, both overall models are to be considered as highly significant. Thus, a causal relationship between the dependent variable and the independent variables is empirically given (Backhaus et al. 2010). Autocorrelation among residuals is excluded as the Durbin-Watson values for both subgroups are close to 2 (1.807 for low country-knowledge respondents and 1.983 for high country-knowledge respondents; see Appendix in Table 9). The same applies to VIF (Variance Inflation Factor) values. These consistently show results below 5, which forecloses multicollinearity. It can therefore be assumed that the components included in the regression model do not correlate with each other (Eckstein 2019). Within the scope of the analysis, there exist no outliers for the product wine from Northern Italy which considerably deviate. Potentially influential outliers can therefore not be identified, since the values of the Cook distance are consistently lower than 1 (Cook and Weisberg 1995). The White-test (see Appendix in Table 10) also indicates homoskedasticity, which means that the distribution of the variance of the statistical error term $\varepsilon$ is subject to a homogeneous distribution, the expected value of the statistical error term is zero and the random variables of the statistical error term are not correlated with each other (so-called white noise) (White 1980). As the determination coefficient for the subgroup of respondents with low country knowledge is $\mathrm{R}^{2}=0.252$, the proportion of the variation of the dependent variable explained by the variation of the independent variable is 25.2 percent. For cross-sectional studies, a value around $R^{2}=0.3$ (i.e. 30 percent of explained variation) of the determination coefficient is regarded as a common reference point for the goodness of fit (Mooi and Sarstedt 2011). Thus, a good quality of fit of the overall model is given. With $\mathrm{R}^{2}=0.169$, the determination coefficient for the subgroup of respondents with high country knowledge shows a lower goodness of fit of the overall model. In conclusion, this means that 16.9 percent of the purchase probability measured in this study can be explained by the variation of independent variables (i.e. affective component, normative component, cognitive component).

Table 3 shows a highly significant influence of the cognitive image on the purchase probability of the product wine from Northern Italy for the subgroup of low country-knowledge respondents. With a significance level of $\mathrm{p}<0.001$, cognitive factors of the Northern Italian image strongly influence purchase probability of wine from Northern Italy, with $\beta=0.717$ ( $\mathrm{SE}=0.126$ ). Thus, the purchase probability for the analysed product increases by 0.717 units if the perception of the cognitive component changes by one unit. At the same time, a significant influence of the affective component of Northern Italy on purchase probability at a significance level of $\mathrm{p}<0.05$ can be observed. A change of the affective component by one unit leads 
Table 3 Results of multiple linear regression analysis for wine from Northern Italy. Source: Own evaluation

Influence of image components on purchase probability of wine from Northern Italy

\begin{tabular}{|c|c|c|c|c|c|}
\hline \multirow[b]{2}{*}{$\begin{array}{l}\text { Country } \\
\text { knowledge }\end{array}$} & \multirow[b]{2}{*}{ Independent variable } & \multicolumn{2}{|c|}{ Regression coefficient } & \multirow[b]{2}{*}{ Standard error } & \multirow[b]{2}{*}{ VIF } \\
\hline & & Unstandardized & Standardized & & \\
\hline \multirow[t]{7}{*}{ Low } & Constant & 0.068 & & 0.446 & \\
\hline & Normative North & -0.111 & -0.66 & 0.133 & 1.896 \\
\hline & Cognitive North & $0.717 * * *$ & $0.456 * * *$ & 0.126 & 1.925 \\
\hline & Affective North & $0.252 *$ & $0.143^{*}$ & 0.124 & 1.491 \\
\hline & $\mathrm{R}^{2}$ & 0.252 & & & \\
\hline & corrected $\mathrm{R}^{2}$ & 0.242 & & & \\
\hline & $\mathrm{F}(\mathrm{df}=3,225)$ & $25.300 * * *$ & & & \\
\hline \multirow[t]{7}{*}{ High } & Constant & 0.449 & & 0.701 & \\
\hline & Normative North & -0.252 & -0.155 & 0.155 & 1.459 \\
\hline & Cognitive North & $0.901 * * *$ & $0.369 * * *$ & 0.214 & 1.315 \\
\hline & Affective North & $0.329 *$ & 0.190 & 0.153 & 1.328 \\
\hline & $\mathrm{R}^{2}$ & 0.169 & & & \\
\hline & Corrected $\mathrm{R}^{2}$ & 0.151 & & & \\
\hline & $\mathrm{F}(\mathrm{df}=3,142)$ & $9.603 * * *$ & & & \\
\hline
\end{tabular}

$* p<0.05 ; * * p<0.01 ; * * * p<0.001$

to an increase of purchase probability by 0.252 units, since $\beta=0.252(\mathrm{SE}=0.124)$. Compared to the cognitive component, however, this influence does not have the same weight.

The subgroup of respondents with high country-knowledge shows a similar result, whereby the influence of the cognitive component on purchase probability with a value of $\beta=0.901(\mathrm{SE}=0.214)$ and a significance value of $\mathrm{p}<0.001$ is highly significant and at the same time stronger than in the subgroup of respondents with low country-knowledge. In conclusion, there is a strong positive relationship between purchase probability and cognitive component of attitude towards Northern Italy. Same applies to the affective component, which influences purchase probability significantly, with $\beta=0.329$ ( $\mathrm{SE}=0.153$ ). Still, as $\mathrm{R}^{2}$ is lower for the subgroup of high country knowledge respondents, the predictive value of the region image for purchase probability decreases with an increasing country knowledge.

With regard to the regression models for Southern Italian wine, Table 4 shows that only the overall model has a significant $F$ value of $F(d f=3,224)=3.659$ $(\mathrm{p}<0.05)$ for the subgroup of respondents with low country knowledge. In the subgroup of high country knowledge, the $\mathrm{F}$-value is with $\mathrm{F}(\mathrm{df}=3,142)=1.175$ below the critical F-value and therefore not significant. Thus, in the case of the subgroup of respondents with a high knowledge of Italy, no causal relationship between the purchase probability of Southern Italian wine and the independent image variables can be observed. This is also reflected in the low proportion of the variation explained by the independent variables $\left(R^{2}=0.042\right)$. The value is at a higher level $\left(R^{2}=0.047\right)$ 
Table 4 Results of multiple linear regression analysis for wine from Southern Italy. Source: Own evaluation

Influence on the purchase probability of wine from Southern Italy

\begin{tabular}{|c|c|c|c|c|c|}
\hline \multirow[b]{2}{*}{$\begin{array}{l}\text { Country } \\
\text { knowledge }\end{array}$} & \multirow[b]{2}{*}{ Independent variable } & \multicolumn{2}{|c|}{ Regression coefficient } & \multirow[b]{2}{*}{ Standard error } & \multirow[b]{2}{*}{ VIF } \\
\hline & & Unstandardized & Standardized & & \\
\hline \multirow[t]{7}{*}{ Low } & Constant & 2.051 & & 0.418 & \\
\hline & Normative South & 0.229 & 0.144 & 0.120 & 1.356 \\
\hline & Cognitive South & 0.227 & 0.131 & 0.139 & 1.350 \\
\hline & Affective South & -0.078 & -0.054 & 0.110 & 1.530 \\
\hline & $\mathrm{R}^{2}$ & 0.047 & & & \\
\hline & corrected $\mathrm{R}^{2}$ & 0.034 & & & \\
\hline & $\mathrm{F}(\mathrm{df}=3,225)$ & $3.659 *$ & & & \\
\hline \multirow[t]{7}{*}{ High } & Constant & 1.829 & & 0.721 & \\
\hline & Normative South & -0.042 & -0.033 & 0.149 & 1.190 \\
\hline & Cognitive South & 0.072 & 0.033 & 0.235 & 1.910 \\
\hline & Affective South & 0.273 & 0.158 & 0.157 & 1.710 \\
\hline & $\mathrm{R}^{2}$ & 0.042 & & & \\
\hline & Corrected $\mathrm{R}^{2}$ & 0.004 & & & \\
\hline & $\mathrm{F}(\mathrm{df}=3,142)$ & 1.175 & & & \\
\hline
\end{tabular}

$* p<0.05 ; * * p<0.01 ; * * * p<0.001$

for the subgroup of respondents with low country knowledge, but is also lower than for Northern Italian wine.

The Durbin-Watson statistics show no autocorrelation among residuals with values of 1.905 for respondents with little knowledge of the country and 2.160 for Italy connoisseurs (see Appendix in Table 10). Collinearity among the independent variables is excluded due to VIF values below 5 . No outliers can be identified, as the Cook distances are consistently below the value of 1 . Homoskedasticity is only given for the subgroup of respondents with high country knowledge. The significant value of the White test for the subgroup of respondents with low country knowledge $(p=0.002<0.05)$ shows that heteroscedasticity is given (see Appendix in Table 11).

This underlines the low explanatory contribution of the measured image to the purchase probability of Southern Italian wine and indicates that this is explained by other factors. It becomes clear that upon closer analysis none of the independent variables has a significant influence on purchase probability of Southern Italian wine. There are no influences to be recognized in the subgroup of respondents with high country knowledge as well as in the subgroup of respondents with low country knowledge.

The fact that the overall model for the low country knowledge subgroup has an $F$ value significantly above the critical $F$ value can be explained by the increased number of degrees of freedom, since the VIF values are below the critical value of 5 . Due to the number of degrees of freedom, the overall model may be sensitive to possible biases in some cases (Bortz and Schuster 2010). In addition, non-linear 
correlation between the individual independent variables is caused by the lack of significance and can also be attributed to the presence of an influential error term.

\section{Discussion}

Summarized, the multiple linear regression reveals that the fact that Northern Italy consistently has a significantly more positive image among consumers in Germany than Southern Italy, translates in the increased positive relationship between the image of Northern Italy and the likelihood of purchase. It is shown, that image perceptions are positively associated with consumer choice (White 2012; Ryu et al. 2016). The results in this regard, with reference to Sect. 2.3.1 and research question 3 indicate the existence of halo effects. Based on the theoretical considerations it is assumed that the subgroup of respondents with a low level of country knowledge, due to their lack of familiarity with Italy and the typical products of the country, relies more strongly on the general associations with Northern Italy. Since Northern Italy is associated with a developed economy and associations with Northern Italy are generally positive especially in the cognitive component, respondents automatically assume that Northern Italian products are of high quality, which decreases risk perception and analogously increases the purchase probability of products of Northern Italian origin, which strengthens the influence of the existing image (halo effect). Since the associations with Southern Italy are rather negative and the region is not associated with the values and characteristics mentioned above, this halo effect does not exist and there is no activation of the Southern Italian image in the purchasing process. The present article thus shows that the image of Southern Italy does not provide consumers in Germany with a suitable decision-making heuristic for buying wine. In contrast to Northern Italy, Southern Italian image therefore does not serve as a suitable extrinsic cue for the respondents to purchase wine.

While, for example, Roth and Romeo (1992) found no evidence for the influence of country knowledge on the purchase probability, with regard to research question 4 this can be seen in this study to the extent that increasing country knowledge weakens the interrelation between regional image and purchase probability. Survey respondents with a high level of country knowledge attach greater importance to information on origin per se, as can be seen from the mean value comparison of purchase probabilities. However, the relationship between the regional images and purchase probability weakens with increasing knowledge of the country. A study of Skuras and Dimara (2016) points in a similar direction, indicating that regional imagery, that is based on personal experiences with a region, decreased average expenditure on regionally denominated Greek wine. With an increased country knowledge, there may be a corresponding higher knowledge of the specific wine regions. This could possibly lead to a reduction of the importance of general image of the region as a whole. Vice versa, consumers with low country knowledge are more responsive to the use of larger regional origin indications as they serve as a suitable extrinsic cue in the evaluation process. This result is in line with the findings of Lee and Ganesh (1999), who also find a weaker influence of the image of a country (a region) with a high level of knowledge of the country. Therefore, it 
is concluded that for this subgroup other factors are involved in the explanation of the purchase probability which are not part of the image (e.g. psychographic or socio-demographic antecedents, such as gender, socio-economic status or age). Sun and Morwitz (2010) show that the consideration of such variables can significantly improve the forecasting of purchasing behaviour. In the course of further research, it therefore seems reasonable to include the latter in the studies. Especially with regard to respondents with a high level of country knowledge, for whom the purchase probability is associated to a lesser extent with the respective image. An analysis of these antecedents could therefore also increase a target-group and segment-oriented approach and thus the practical relevance for managers.

A further approach to better understand the effect of larger regional indications, could be to connect them together with traditionally used wine regions on wine labels (such as Chianti, Barolo etc.), as applied by Bruwer and Johnson (2010). They showed that the use of larger regions in combination with traditionally used wine regions significantly increased consumer preference. While these results focus on "New world" wines from the USA, this can be investigated in further detail for European respectively Italian wines in the future, for which the present work provides a first basis.

As stated in Sect. 3, a consideration of the national image or the regional image only has relevance for marketing practice if it is identified as a purchase-relevant attribute of the corresponding product (Möller 1997; von Alvensleben 2001) and when consumers acknowledge a connection between wine and the respective region (Waiguny et al. 2017). On the basis of the results of this study, this cannot be substantiated for Southern Italian wine. The results show that this is the case for Northern Italy. In fact, there is a higher goodness of fit of the regression models for Northern Italian wine, which suggests that the likelihood of purchasing Northern Italian wine can be explained to a greater extent by the Northern Italian image. For Southern Italy, this connection does not seem to be present in the respondents' perception, which is why no positive or negative influence on the purchase probability can be identified. In contrast to the regression models for Northern Italy, goodness of fit of the regression models for Southern Italy remains relatively low. Finally, the influence of sympathy for a region on the probability of buying a wine falls in line with other findings, which, especially for this product, ascertain an influence of positive attitudes (affective component) as well as cognitive aspects on consumer perception (van Ittersum 2002; Latusi et al. 2018). Even though the normative image differs significantly between Northern and Southern Italy, it has no discernible influence on purchase probability. In conclusion, analogously to van Ittersum (2002), White (2012), Ryu et al. (2016), it is observed that the better the image, the more likely it is to influence consumer choice. In order to take into account normative considerations of image more accurately, future research should build on an extensive theoretical grounding of the latter, which then reflects in a comprehensive item battery.

As a limitation, it is noted that the present study only measures the purchase probability on a single-item 5-point scale. In the future, it is preferable to use established measuring methods that capture the purchase probability more adequately. Such as multi-item "willingness-to-pay" scales, as used by Koschate-Fischer et al. (2012). Although these require greater effort in the execution of the test, they allow more reliable conclusions to be drawn due to their more realistic character. In addition, it seems to be preferable to use a between-subjects design rather than a withinsubjects design, which is used in this work. Although such an approach requires two 
independent samples, it avoids possible learning effects during test participation and thus more valid results (Kuß et al. 2018). A further methodological improvement can be achieved by implementing a second-order structural equation model, which is conceptually based on a more balanced item battery with a comparable number of items for all image dimensions. Especially with regard to the overrepresentation of cognitive items, this has to be conceptionally considered in future work. As Cronbachs alpha showed good to excellent values for all image dimensions, a SEM approach is indicated. Lastly, as it was the aim of this study to analyse general image, product-related items in the questionnaire were not suited to the product wine, but asked for the general perception of products from the respective region. In order to further refine the results, these items could be suited to wine.

Based on the results, the development of larger regional brands could be a suitable way to positively influence consumer behaviour, especially for consumers with little connection to Italy as a country. However, this is limited to Northern Italy and shows that a Southern Italian indication of origin does not (yet) offer a positive influence on consumer behaviour regarding wine. The Italian economic and cultural north-south divide may thus influence the purchasing behaviour of Italian wine in Germany, for which this study provides initial evidence. In conclusion there seems to exist a tendency that the competitive advantage for Italian products identified by De Nisco and Mainolfi (2016), is mainly concentrated on products of Northern Italian origin. As such, it cannot yet be used for Southern Italian products to contribute to a positive positioning on the (German) consumer goods market. As generally discussed in Sect. 2.4, this study illustrates that specifically the collective reputation of Southern Italy tends to have no value adding effect for wineries. Therefore, when developing marketing strategies, managers should be aware that while there is not necessarily a negative effect, a larger regional indication may not have any effect on consumer choice. Since an incorrect assignment of example regions from northern and southern Italy could not be excluded by the respondents in Germany (see Sect. 1), especially for those having low country knowledge, the focus was on Northern and Southern Italy as independent and overarching entities. In order to rule out such an incorrect assignment as best as possible and to refine the analysis and its managerial implications, it is essential for future studies to identify the most well-known northern and southern Italian regions among consumers in Germany, which is to this date a rather less developed field. These could then be used as representative for the respective northern and southern Italian area. Still, further research should address this issue, taking into account the proposed improvements, that are discussed in this paper. Especially, as consumption is moving increasingly towards international markets, extending the geographical spread of respondents to other countries is of special interest.

Hence, the relevance of this paper is threefold. (1) It does show that the composition of the Italian image shows regional North-South tendencies, (2) it shows, that these discrepancies influence the actual respondents choice behaviour by regarding a positive image as a suitable extrinsic cue for decision making and (3), it offers some evidence, that larger regional indication of origin can, at least for Northern Italy, improve choice behaviour. Having this said, this work offers a first basis for further research concerning the positioning of Italian products in international markets, taking into account the specifics of the Italian image. 


\section{Appendix}

See Tables 5, 6, 7, 8, 9, 10, 11.

Table 5 Operationalisation of the image construct in the questionnaire. Source: own analysis; Ghvanidze (2012) and Buhmann (2016)

\begin{tabular}{|c|c|}
\hline Image dimension & Items* \\
\hline Normative component & $\begin{array}{l}\text { Northern/Southern Italy... } \\
\text {...represents very high social standards } \\
\text {...represents values and beliefs that are consistent with my own beliefs }\end{array}$ \\
\hline Affective component & $\begin{array}{l}\text { Northern Italy/Southern Italy... } \\
\ldots \text { is a hospitable region } \\
\ldots \text { is a place of origin of very beautiful cultural heritage (e.g. build- } \\
\text { ings/architecture, music, film, art, etc.) } \\
\text {..has a fascinating history } \\
\text {..has appealing traditions } \\
\ldots \text { has beautiful landscapes } \\
\ldots \text { is a likeable region } \\
\ldots \text { is an attracting region }\end{array}$ \\
\hline Cognitive component & 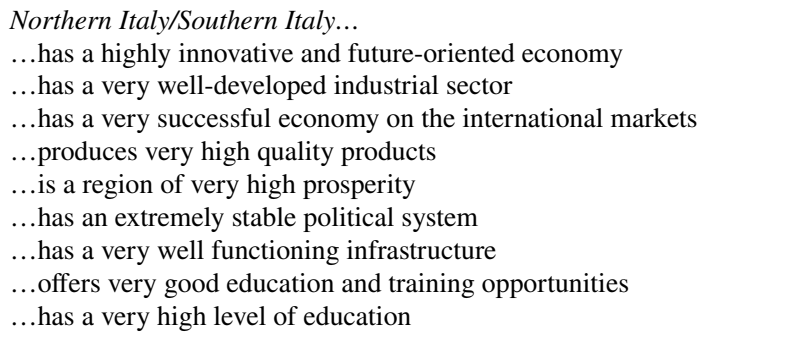 \\
\hline Cognitive component & $\begin{array}{l}\text { Products from Northern Italy/Southern Italy... } \\
\ldots \text {. have a good value for money } \\
\text {...increase my reputation among friends and family } \\
\text {...have a great reputation } \\
\text {...distinguish me as a connoisseur } \\
\ldots \text {. are very expensive } \\
\ldots \text { are of high quality } \\
\ldots \text {.. are of constant quality } \\
\ldots \text {..bring back pleasant memories } \\
\ldots \text {.. are affordable }\end{array}$ \\
\hline
\end{tabular}

*The items were shown in German to the respondents 
Table 6 Reliability statistics for the item aggregation into image components. Source: Own analysis

Table 7 Kolmogorov-Smirnov test for normality of the image components

\begin{tabular}{lll}
\hline Image dimension & $\begin{array}{l}\text { Number } \\
\text { of items }\end{array}$ & Cronbachs alpha \\
\hline Cognitive Northern Italy & 18 & 0.918 \\
Cognitive Southern Italy & 18 & 0.914 \\
Affective Northern Italy & 7 & 0.877 \\
Affective Southern Italy & 7 & 0.917 \\
& & Spearman-Brown coefficient \\
Normative Northern Italy & 2 & 0.731 \\
Normative Southern Italy & 2 & 0.773 \\
\hline
\end{tabular}

\begin{tabular}{lll}
\hline Image dimension & Value & Significance \\
\hline Affective Northern Italy & 0.106 & 0.000 \\
Affective Southern Italy & 0.108 & 0.000 \\
Normative Northern Italy & 0.200 & 0.000 \\
Normative Southern Italy & 0.195 & 0.000 \\
Cognitive Northern Italy & 0.075 & 0.001 \\
Cognitive Southern Italy & 0.081 & 0.000 \\
\hline
\end{tabular}

Table 8 Kolmogorov-Smirnov test for normality of the purchase probabilities

\begin{tabular}{lllll}
\hline & Origin & $\begin{array}{l}\text { Country } \\
\text { knowl- } \\
\text { edge }\end{array}$ & Value & Significance \\
\hline Purchase probability & Purchase probability Northern Italian wine & Low & 0.178 & 0.000 \\
& Purchase probability Southern Italian wine & High & 0.117 & 0.002 \\
& Low & 0.183 & 0.000 \\
& $\begin{array}{c}\text { Purchase probability wine without indication } \\
\text { of origin }\end{array}$ & High & 0.131 & 0.000 \\
& Low & 0.256 & 0.000 \\
& High & 0.331 & 0.000 \\
\hline
\end{tabular}

Table 9 Durbin-Watson statistics for the regression model (wine from Northern Italy)

\begin{tabular}{llll}
\hline $\begin{array}{l}\text { Country knowl- } \\
\text { edge }\end{array}$ & $\mathrm{R}^{2}$ & Corrected $\mathrm{R}^{2}$ & $\begin{array}{l}\text { Durbin- } \\
\text { Watson } \\
\text { value }\end{array}$ \\
\hline Llow & 0.252 & 0.242 & 1.807 \\
High & 0.169 & 0.151 & 1.983 \\
\hline
\end{tabular}


Table 10 Durbin-Watson statistics for the regression model (wine from Southern Italy)

Table 11 White test for variance homogeneity of the statistical error terms

\begin{tabular}{llll}
\hline $\begin{array}{l}\text { Country knowl- } \\
\text { edge }\end{array}$ & $\mathrm{R}^{2}$ & Corrected $\mathrm{R}^{2}$ & $\begin{array}{l}\text { Durbin- } \\
\text { Watson } \\
\text { value }\end{array}$ \\
\hline Low & 0.047 & 0.034 & 1.905 \\
High & 0.024 & 0.004 & 2.160 \\
\hline
\end{tabular}

\begin{tabular}{lll}
\hline Country knowledge & Regression model & $\begin{array}{l}\text { Significance } \\
(\mathrm{p}<0.05)\end{array}$ \\
\hline Low & Northern Italian wine & 0.229 \\
& Southern Italian Wine & 0.002 \\
High & Northern Italian wine & 0.097 \\
& Southern Italian wine & 0.180 \\
\hline
\end{tabular}

Funding Open Access funding enabled and organized by Projekt DEAL.

Open Access This article is licensed under a Creative Commons Attribution 4.0 International License, which permits use, sharing, adaptation, distribution and reproduction in any medium or format, as long as you give appropriate credit to the original author(s) and the source, provide a link to the Creative Commons licence, and indicate if changes were made. The images or other third party material in this article are included in the article's Creative Commons licence, unless indicated otherwise in a credit line to the material. If material is not included in the article's Creative Commons licence and your intended use is not permitted by statutory regulation or exceeds the permitted use, you will need to obtain permission directly from the copyright holder. To view a copy of this licence, visit http://creativecommons.org/licen ses/by/4.0/.

\section{References}

ADM - Arbeitskreis Deutscher Markt- und Sozialforschungsinstitute e.V. (2018). Jahresbericht 2017. https://www.adm-ev.de/w-content/uploads/2018/08/ADM_Jahresbericht_2017_Web-6.pdf. Accessed 14 June 2019.

Ahmed, S., \& d'Astous, A. (2008). Antecedents, moderators and dimensions of country-of-origin evaluations. International Marketing Review, 25(1), 75-106. https://doi.org/10.1108/02651330810851890.

Ahmed, U., Johnson, J., Yang, X., Kheng, C., Sack Teng, H., \& Chee Boon, L. (2004). Does country of origin matter for low-involvement products? International Marketing Review, 21(1), 102-120. https ://doi.org/10.1108/02651330410522925.

Allred, A., Chakraborty, G., \& Miller, S. (2000). Measuring Images of Developing Countries: A Scale Development Study. Journal of Euromarketing, 8(3), 29-49. https://doi.org/10.1300/j037v08n03 02 .

Alvensleben, v. R. (2001). Die Bedeutung von Herkunftsangaben im regionalen Marketing. In: Informationszentrum Genetische Ressourcen von ZADI und des Landesschafzuchtverbands Niedersachsen e.V. of the Symposium „Vielfalt auf dem Markt“. Sulingen, Germany, 2001.

Amyot, G. (2004). Business, the state and economic policy: The case of Italy. London, New York: Routledge.

Andéhn, M., Gloukhovtsev, A., Schouten, J. (2016). The country of origin effect-Key issues and future direction. In Bridging Asia and the World: Global Platform for Interface between Marketing and Management. Proceeding of the Global marketing conference in Hong Kong, 2016. Global Alliance 
of Marketing and Management Associations, pp. 1746-1754. https://doi.org/10.15444/gmc20 16.12.02.04

Astous, A., \& Boujbel, L. (2007). Positioning countries on personality dimensions: Scale development and implications for country marketing. Journal of Business Research, 60(3), 231-239. https://doi. org/10.1016/j.jbusres.2006.11.005.

Atkin, Thomas, \& Johnson, Ray. (2010). Appellation as an indicator of quality. International Journal of Wine Business Research, 22(1), 42-61. https://doi.org/10.1108/17511061011035198.

Backhaus, K., Erichson, B., Plinke, W., \& Weiber, R. (2010). Multivariate Analysemethoden. Berlin: Springer.

Balogh, J., \& Jámbor, A. (2017). The global competitiveness of European wine producers. British Food Journal, 119(9), 2076-2088. https://doi.org/10.1108/BFJ-12-2016-0609.

Bänsch, A. (2002). Käuferverhalten. Berlin: De Gruyter.

Bergler, R. (2013). Identität und Image. In Bentele, G., Fröhlich, R., Szyszka, P. (Eds.) Handbuch der Public Relations. Wissenschaftliche Grundlagen und berufliches Handeln. Wiesbaden: Springer.

Blanz, M. (2015). Forschungsmethoden und Statistik für die Soziale Arbeit. Grundlagen und Anwendungen, Stuttgart: Kohlhammer.

Bloemer, J., Brijs, K., \& Kaser, H. (2009). The CoO-ELM model. European Journal of Marketing, 43(1/2), 62-89. https://doi.org/10.1108/03090560910923247.

Bortz, Jürgen, \& Schuster, C. (2010). Statistik für Human- und Sozialwissenschaftler. Berlin: Springer.

Bruner, J. S., Austin, G. A., \& Goodnow, J. (1956). A study of thinking. New York, London, Sydney: John Wiley \& Sons.

Bruwer, J., \& Johnson, R. (2010). Place-based marketing and regional branding strategy perspectives in the California wine industry. Journal of Consumer Marketing, 27(1), 5-16. https://doi. org/10.1108/07363761011012903.

Buhmann, A. (2016). Measuring country image: Theory, method, and effects. Wiesbaden: Springer.

Bundesministerium für Wirtschaft und Energie - BMWi (2019): Fakten zum Außenhandel. https://www. bmwi.de/Redaktion/DE/Publikationen/Aussenwirtschaft/fakten-zum-deuschen-aussenhandel.pdf? blob=publicationFile $\& v=34$.

Celsi, R. L., \& Olson, J. C. (1988). The Role of Involvement in Attention and Comprehension Processes. Journal of Consumer Research, 15(2), 210-224. https://doi.org/10.1086/209158.

Chamorro, A., Rubio, S., \& Miranda, F. J. (2015). The region-of-origin (ROO) effect on purchasing preferences. British Food Journal, 117(2), 820-839. https://doi.org/10.1108/BFJ-03-2014-0112.

Cohen, J. (1988). Statistical power analysis for the behavioral sciences. Hillsdale: Lawrence Erlbaum Associates.

Conca Messina, S., Le Bras, S., Tedeschi, P., Vaquero Piñeiro, M. (2019). Terroir, Institutions and Improvements in European Wine History. An Introduction. In: Conca Messina, S., Le Bras, S., Tedeschi, P., Vaquero Piñeiro, M. (Eds.): A History of Wine in Europe, 19th to 20th Centuries, Volume I. Cham: Springer International (Palgrave Studies in Economic History).

Cook, D. R., \& Weisberg, S. (1995). Residuals and influence in regression. London: Chapman and Hall.

Correia, L., Gouveia, S., \& Martins, P. (2019). The European wine export cycle. Wine Economics and Policy, 8(1), 91-101. https://doi.org/10.1016/j.wep.2019.04.001.

De Nisco, A., \& Mainolfi, G. (2016). Competitiveness And Foreign Perception Of Italy And Made In Italy On The Emerging Markets. Rivista Italiana di Economia, Demografia e Statistica - Italian Review of Economics, Demography and Statistics, 70(3), 15-28.

De Nisco, A., Mainolfi, G., Marino, V., \& Napolitano, M. R. (2016). Effect of economic animosity on consumer ethnocentrism and product-country images: A binational study on the perception of Germany during the Euro crisis. European Management Journal, 34(19), 59-68. https://doi. org/10.1016/j.emj.2015.09.003.

Eckstein, (2019). Statistik für Wirtschaftswissenschaftler. Berlin: Springer.

Eisinga, R., Grotenhuis, M., \& Pelzer, B. (2013). The reliability of a two-item scale: Pearson, Cronbach, or Spearman-Brown? International Journal of Public Health, 58(4), 637-642. https://doi. org/10.1007/s00038-012-0416-3.

Fauser, S. (2011). Modeling regional labor markets in Germany: Insights not only for German policy makers. Empirica, 38(2), 169-201. https://doi.org/10.1007/s10663-010-9128-1.

Foscht, T., Swoboda, B., \& Schramm-Klein, H. (2017). Käuferverhalten. Wiesbaden: Springer.

Fournier, S. (1998). Consumers and Their Brands: Developing Relationship Theory in Consumer Research. Journal of Consumer Research, 24(4), 343-353. https://doi.org/10.1086/209515. 
Future Brand (2015). Made In. The value of Country of Origin for future brands. http://www.futurebran d.com. Accessed 25 July 2019.

Ghvanidze, S. (2012). Bedeutung des Country-of-Origin-Effekts für die Wahrnehmung deutscher Weinkonsumenten. Eine Untersuchung am Beispiel des georgischen Weins. Göttingen: Cuvillier (Internationale Reihe Agribusiness).

Han, C. M. (1989). Country Image: Halo or Summary Construct? Journal of Marketing Research, 26(2), 222-229. https://doi.org/10.2307/3172608.

Hoffmann, S., Mai, R., \& Smirnova, M. (2014). Development and Validation of a Cross-Nationally Stable Scale of Consumer Animosity. Journal of Marketing Theory and Practice, 19(2), 235-252. https:// doi.org/10.2753/MT1069-6679190208.

ISTAT - Istituto Nazionale di Statistica (2018) Import and export by country and commodity Nace 2007. http://dati.istat.it/OECDStat_Metadata/ShowMetadata.ashx?Dataset=DCS_COEIMEX1\&ShowO nWeb=true\&Lang=en. Accessed 25 June 2019.

ISTAT - Istituto Nazionale di Statistica (2019). Annuario Statistico Italiano, Rome.

Jansen, C. (2012). Uneiniges Italien. Die „Südfrage“als Strukturproblem vom Risorgimento bis heute. In Minelli, M., Schlösser, R. (Ed.), 150 Jahre einiges Italien (pp. 179-202). Munich: Martin Meidenbauer.

Johnson, R., \& Bruwer, J. (2007). Regional brand image and perceived wine quality: The consumer perspective. International Journal of Wine Business Research, 19(4), 276-297. https://doi. org/10.1108/17511060710837427.

Kelman, H. (1965). Social-psychological approaches to the study of international relations: The question of relevance. In H. C. Kelman (Ed.), International behaviour (pp. 565-607). New York: Holt, Rinehart and Winston.

Klein, J. G., Smith, N. C., \& John, A. (2004). Why We Boycott: Consumer Motivations for Boycott participation. Journal of Marketing, 68(3), 92-109. https://doi.org/10.1509/jmkg.68.3.92.34770.

Koschate-Fischer, N., Diamantopoulos, A., \& Oldenkotte, K. (2012). Are Consumers Really Willing to Pay More for a Favorable Country Image? A Study of Country-of-Origin Effects on Willingness to Pay. Journal of International Marketing, 20(1), 19-41. https://doi.org/10.1509/jim.10.0140.

Kraigher-Krainer, J. (2007). Das ECID-Modell. Wiesbaden: Gabler.

Kroeber-Riel, W., Gröppel-Klein, A. (2013). Konsumentenverhalten. Munich: Vahlen (Vahlens Handbücher der Wirtschafts- und Sozialwissenschaften).

Kühn, R. (1993). Das “Made-in-Image” Deutschlands im internationalen Vergleich. Marketing ZF Journal of Research and Management, 15(2), 119-128. https://doi.org/10.15358/0344-1369-1993-2-119.

Kuß, A., Wildner, R., \& Kreis, H. (2018). Marktforschung. Datenerhebung und Datenanalyse. Wiesbaden: Gabler.

Kwon, H. (2004). Associations, Civic Norms, and Democracy: Revisiting the Italian Case. Theory and Society, 33(2), 135-166.

Laroche, M., Papadopoulos, N., Heslop, L., \& Mourali, M. (2005). The influence of country image structure on consumer evaluations of foreign products. International Marketing Review, 22(1), 96-115. https:// doi.org/10.1108/02651330510581190.

Latusi, S., Zerbini, C., Maestripieri, S., \& Luceri, B. (2018). Wine Marketing: Consumer persuasion through the Region of Origin. International Journal of Business and Management, 13(7), 137-145. https://doi. org/10.5539/ijbm.v13n7137.

Lebrenz, S. (1996). Länderimages: Einflussfaktor und Bedeutung für das Konsumentenverhalten. Eine empirische Studie bei langlebigen Gebrauchsgütern, Cologne: Lohmar.

Lee, D., \& Ganesh, G. (1999). Effects of partitioned country image in the context of brand image and familiarity. International Marketing Review, 16(1), 18-41. https://doi.org/10.1108/02651339910257610.

Lockshin, L., Jarvis, W., d'Hauteville, F., \& Perrouty, J. (2006). Using simulations from discrete choice experiments to measure consumer sensitivity to brand, region, price, and awards in wine choice. Food Quality and Preference, 17(3-4), 166-178. https://doi.org/10.1016/j.foodqual.2005.03.009.

Maheswaran, D., \& Chen, C. Y. (2006). Nation Equity: Incidental Emotions in Country-of-Origin Effects. Journal of Consumer Research, 33(3), 370-376. https://doi.org/10.1086/508521.

Mai, R. (2011). Der Herkunftslandeffekt: Eine kritische Würdigung des State of the Art. Journal für Betriebswirtschaft, 61(2), 91-121. https://doi.org/10.1007/s11301-011-0075-0.

Martin, I., \& Eroglu, S. (1993). Measuring a multi-dimensional construct. Country image. Journal of Business Research, 28(3), 191-210. https://doi.org/10.1016/0148-2963(93)90047-S. 
Messina, M. (2018). The demonization of the South and the Southernification of evil in contemporary Italian cinema: Belluscone and Qualunquemente. Journal of Italian Cinema \& Media Studies, 6(2), 193-207. https://doi.org/10.1386/jicms.6.2.193_1.

Ministero delle politiche agricole alimentari e forestali (MiPAAF). Prodotti DOP, IGP e STG. https:// www.politicheagricole.it/flex/cm/pages/ServeBLOB.php/L/IT/IDPagina/396

Möller, T. (1997). Landesimage und Kaufentscheidung: Erklärung, Messung, Marketingimplikationen. Wiesbaden: Deutscher Universitätsverlag.

Mooi, E., \& Sarstedt, M. (2011). A Concise Guide to Market Research: The Process, Data, and Methods Using IBM SPSS Statistics. Berlin: Springer.

Oberecker, E. M., Riefler, P., \& Diamantopoulos, A. (2008). The Consumer Affinity Construct: Conceptualization, Qualitative Investigation, and Research Agenda. Journal of International Marketing, 16(3), 23-56. https://doi.org/10.1509/jimk.16.3.23.

Okechuku, C. (1994). The Importance of Product Country of Origin. European Journal of Marketing, 28(4), 5-19. https://doi.org/10.1108/03090569410061150.

Orth, U. R., McGarry Wolf, M., \& Dodd, T. H. (2005). Dimensions of wine region equity and their impact on consumer preferences. Journal of Product \& Brand Management, 14(2), 88-97. https://doi. org/10.1108/10610420510592563.

Park, J., Park, K., \& Dubinsky, A. (2011). Impact of retailer image on private brand attitude: Halo effect and summary construct. Australian Journal of Psychology, 63(3), 173-183. https://doi.org/10.111 1/j.1742-9536.2011.00015.x.

Peter, J., \& Olson, J. (2010). Consumer behavior (9th ed.). New York, London: McGraw-Hill.

Peterson, R. A., \& Jolibert, A. J. (1995). A Meta-Analysis of Country-of-Origin Effects. Journal of International Business Studies, 26(4), 883-900. https://doi.org/10.1057/algrave.jibs.8490824.

Pharr, J. (2015). Synthesizing Country-of-Origin Research from the Last Decade: Is the Concept Still Salient in an Era of Global Brands? Journal of Marketing Theory and Practice, 13(4), 34-45. https://doi. org/10.1080/10696679.2005.11658557.

Profeta, A. (2006). Der Einfluss geschützter Herkunftsangaben auf das Konsumentenverhalten bei Lebensmitteln. Eine Discrete-Choice-Analyse am Beispiel Bier und Rindfleisch. Hamburg: Kovač (Studien zum Konsumentenverhalten).

Pucci, T., Casprini, E., Guercini, S., \& Zanni, L. (2017). One country, multiple country-related effects: An international comparative analysis among emerging countries on Italian fashion products. Journal of Global Fashion Marketing, 8(2), 98-112. https://doi.org/10.1080/20932685.2016.1274666.

Pucci, T., Rabino, S., Zanni, L. (2014). Region of Origin and product knowledge. A cross-national analysis of the purchasing decisions of Chianti Classico wine.

Roth, K., \& Diamantopoulos, A. (2009). Advancing the country image construct. Journal of Business Research, 62(7), 726-740. https://doi.org/10.1016/j.jbusres.2008.05.014.

Roth, M. S., \& Romeo, J. B. (1992). Matching Product Category and Country Image Perceptions: A Framework for Managing Country-of-Origin Effects. Journal of International Business Studies, 23(3), 477497. https://doi.org/10.1057/algrave.jibs.8490276.

Ryu, J., L'Espoir Decosta, P., \& Andéhn, M. (2016). From branded exports to traveler imports. Building destination image on the factory floor in South Korea. Tourism Management, 52, 298-309. https://doi. org/10.1016/j.tourman.2015.07.004.

Samiee, S., Shimp, T. A., \& Sharma, S. (2005). Brand origin recognition accuracy: Its antecedents and consumers' cognitive limitations. Journal of International Business Studies, 36(4), 379-397. https://doi. org/10.1057/algrave.jibs.8400145.

Scarpa, R., \& Del Giudice, T. (2004). Market Segmentation via Mixed Logit: Extra-Virgin Olive Oil in Urban Italy. Journal of Agricultural \& Food Industrial Organization, 2(7), 479-497. https://doi. org/10.2202/1542-0485.1080.

Schooler, R. D. (1965). Product Bias in the Central American Common Market. Journal of Marketing Research, 2(4), 394-397. https://doi.org/10.2307/3149486.

Shapiro, C. (1982). Consumer Information, Product Quality, and Seller Reputation. The Bell Journal of Economics, 13(1), 20-35. https://doi.org/10.2307/3003427.

Skuras, D., \& Dimara, E. (2016). Regional Image and the Consumption of Regionally Denominated Products. Urban Studies, 41(4), 801-815. https://doi.org/10.1080/0042098042000194115.

Sun, B., \& Morwitz, V. G. (2010). Stated intentions and purchase behavior: A unified model. International Journal of Research in Marketing, 27(4), 356-366. https://doi.org/10.1016/j.ijresmar.2010.06.001.

Triulzi, U. (2016). Italy and the challenge of an economic, monetary and "political". Rivista Italiana di Economia Demografia e Statistica - Italian Review of Economics, Demography and Statistics, 70(3), 5-13. 
Tustin, M., \& Lockshin, L. (2001). Region of origin. Does it really count? Australian and New Zealand Wine Industry Journal, 16, 139-143.

van Ittersum, K. (2002). The role of region of origin in consumer decision-making and choice. Den Haag: Mansholt Graduate School.

Verlegh, W., \& Steenkamp, J. (1999). A review and meta-analysis of country-of-origin research. Journal of Economic Psychology, 20(5), 521-546. https://doi.org/10.1016/S0167-4870(99)00023-9.

Waiguny, M., Redl, L., Kotek, K. (2017). Market matters! - Innovative Entscheidungen und Entwicklungen im Marketing und Konsumentenverhalten. Country of Origin: Der Effekt von Regionsinformation", paper resented at the Forschungsforum der Österreichischen Fachhochschulen (FFH), 19 April - 20 April 2017, Krems, Austria, available at: http://ffhoarep.fh-ooe.at/handle/123456789/1048 (accessed 18 March 2019).

Wall, M., \& Heslop, L. A. (1986). Consumer attitudes toward Canadian-made versus imported products. Journal of the Academy of Marketing Science, 14(2), 27-36. https://doi.org/10.1007/BF02722154.

Wallendorf, M., \& Reilly, M. D. (1983). Ethnic Migration, Assimilation, and Consumption. Journal of Consumer Research, 10(3), 292-302. https://doi.org/10.1086/208968.

White, H. (1980). A Heteroskedasticity-Consistent Covariance Matrix Estimator and a Direct Test for Heteroskedasticity. Econometrica, 48(4), 817-838. https://doi.org/10.2307/1912934.

White, C. (2012). Brands and national image: An exploration of inverse country-of-origin effect. Place Brand and Public Diplomacy, 8(2), 110-118. https://doi.org/10.1057/pb.2012.6.

Winfree, J., \& McCluskey, J. (2005). Collective Reputation and Quality. American Journal of Agricultural Economics, 87(1), 206-213. https://doi.org/10.1111/j.0002-9092.2005.00712.x.

Zajonc, R. B., \& Markus, H. (1982). Affective and Cognitive Factors in preferences. Journal of Consumer Research, 9(2), 123-131. https://doi.org/10.1086/208905.

\section{Authors and Affiliations}

\section{Simon Fauser ${ }^{1}\left[{ }^{10} \cdot\right.$ David Agola $^{1}$}

Simon Fauser

Simon.Fauser@HS-Heilbronn.de

1 Faculty of International Business, Heilbronn University, Heilbronn, Germany 